\title{
Development of Fitting Training Programs for Victims of Drug Abuse in the Social and Human Resource Rehabilitation Center BRSPP DIY
}

\author{
$1^{\text {st }}$ Arifin Ika Nugroho* \\ Department of Physical Education, \\ Health, and Recreation \\ Universitas Musamus \\ Merauke, Indonesia \\ arifin@unmus.ac.id
}

\author{
$2^{\text {st }}$ Pulung Riyanto \\ Department of Physical Education, \\ Health, and Recreation \\ Universitas Musamus \\ Merauke, Indonesia \\ riyanto_fkip@unmus.ac.id
}

\author{
$3^{\text {st }}$ Syamsudin \\ Department of Physical Education \\ Health, and Recreation \\ Universitas Musamus \\ Merauke, Indonesia \\ syamsudin@unmus.ac.id
}

\begin{abstract}
This study aims to produce a book product "Based Sport Activities Management" Fitness Training Program Guidelines for Victims of Drug Abuse in the Social Service and Rehabilitation Center BRSPP Special Region of Yogyakarta. The product developed is expected to be used by practitioners and victims of drug abuse as a form of exercise model that is good and effective in improving fitness. This developmental research was carried out with the following research steps: (1) preliminary study, (2) planning, (3) initial draft design, (4) validation of initial and revised drafts, (5) small-scale trials and revisions, (6) large-scale trials and revisions, (7) final products, and (8) effectiveness tests. Based on the results of the study, it can be concluded that there is a significant increase in physical fitness status after drug abuse victims are given a physical condition training program, which is proven by obtaining a calculated $t$ value of 11,008 which is greater than $t$ table $2.131(11.008>2.131)$.
\end{abstract}

Keywords: conditions, physical, fitness and drug

\section{INTRODUCTION}

This Drug abuse is a social problem that has very broad negative impacts. Cases of drug abuse in Indonesia that have not been resolved and the rampant cases of drug abuse threaten Indonesia's progress. Compared to the 2011 study, the prevalence rate was relatively stable $(2.2 \%)$ but there was an increase compared to the 2008 study results $(1.9 \%)$. The results of the projection of drug abuse calculations are divided into 3 scenarios, namely the up scenario, the stable scenario, and the down scenario. In the rising scenario, the number of abusers will increase from 4.1 million (2014) to 5.0 million people (2020).In connection with this problem, the government seeks to suppress the demand (Demand Reduction) of drugs by issuing a number of policies and legislation and regulations, among others, Narcotics Act No. 35 of 2009 concerning Narcotics article 54 that addicts and victims of drug abuse must undergo Medical Rehabilitation and Social Rehabilitation [1].

Seen from the biopsychosocial model, drug abusers are seen as a 'relapsing' disease that requires lifelong recovery. In other words, in the world of addiction not knowing the word cure for drug addicts, what is there is recovering [1]. So, the recovery effort in drug abuse is not an easy problem.
It takes a long time, serious effort, and high discipline for abusers to survive free of Substance. Some literature with the Rehabilitation Program which has many approaches shows success in helping addicts through the recovery process, especially if they follow the program as a whole [2]

Troubleshooting (Interventions) and impacting positive to the addicts themselves in Rehabilitation, is one of the right ways of many attempts to try to improve and improve the quality of Therapy and Rehabilitation services that are in the process of targeting improvements from the Government [3]. Therefore, reinforcement should be carried out on all the patterns of implementation of interventions that have been listed in the implementation guidelines that have been prepared by the Central Government / State.

The emphasis of the discussion that researchers hope for in this study is the problem-solving plan in Physical Guidance and Health in the process of Social Rehabilitation and assistance for Victims of Drug Abuse. The development of renewal of educational technology requires the improvement of the quality of learning resources and development towards a better direction [4]. The results showed that a brief exercise-based screen and consultation tailored to adolescent health habits, with and without parent ingredients, could potentially reduce alcohol use while increasing exercise frequency [5].

Based on the above research results and other related studies show that Sports Activities carried out correctly, measured, progressive and programmed really have a positive impact on the Quality of Health and Life of Sports Persons. Together we understand that the nature of Physical Election in this case Sports activities not only include physical activity, but also involve the human psychological element. In the declaration of the International Council of Sport and Physical Education, it is stated that Sports is any physical activity that is a game and in the form of a struggle against oneself or others or against certain natural forces. Tests and measurements are an important science in order to support sports coaching [6].

Sports activities affect the formation of values, leadership, motivation and creativity, and can affect one's life, because human life is influenced by physical, 
psychological and social, this is in accordance with the basics of sport, namely: 1) sports are physical,; 2) Sports are spiritual,; 3) sports are sociological, meaning that sports provide opportunities to increase relationships and fill leisure time [7].

In connection with these problems, the authors are interested in compiling the Development of Fitness Exercise Program Guidelines in a simple way that can be a choice of Physical Activity for Victims of Drug Abuse in undergoing a Social Rehabilitation Program and in the general Community in a consistent and orderly manner [1]. In principle, regular exercise is a process of change for the better, namely improving: physical quality, functional ability of body equipment, and psychological quality of a person [8]. Thus, after understanding some outlines in Sport, in the Social Rehabilitation Process we can start some light Sports activities but do it regularly and have the quality according to the references given, for example Jogging, BodyWeight Training, Several types of group Games, Yoga, Koex and balanced with nutritious food intake. So that it helps the implementation of problem-solving interventions in the Physical Guidance and Health (Personal Hygiene), values in life that are characteristic of sports, leadership behavior, stimulating to strengthen motivation in life goals, and getting comfort in the process of himself thinking to strengthen harmony and keep motivated to recover from drugs [7].

The Social Rehabilitation Center for drug victims is considered as an effort to provide treatment for victims to be able to recover from their condition and be able to avoid being caught in drugs [9]. Because cholesterol in the body is essential for producing cell membranes, the production of the hormones estrogen and testosterone as well as vitamin D and bile acids which help in proper digestion of fats [8]. The role of the Social Rehabilitation Center for NAPZA victims is seen as important in providing strategies to improve the recovery of victims of drug abuse.

Pamardi Putra Social Rehabilitation Center Yogyakarta is an institution that researchers choose as a place of research on the grounds that it will get good data validity because Victims of Drug Abuse are Inpatients. The urgency of the research is that to compile Alternative Fitness Activity Development Guidelines in the recovery process using the Fitness Exercise Program and Healthy Lifestyle for Victims of Drug Abuse. As well as fostering awareness of the importance of maintaining physical health of individuals and the embedded values of discipline through Sports Activities.

\section{RESEARCH METHODS}

This research method is a research development or Research and Development is a research method used to produce certain products and test the effectiveness of these products [9]. The flow of research is as follows: (1) preliminary study, (2) planning, (3) initial draft design, (4) validation of initial and revised drafts, (5) small-scale and revised trials, (6) large-scale trials and revision, (7) final product, and (8) effectiveness test. A small-scale trial was conducted on four officers and 6 victims of drug abuse. A large-scale trial was conducted on four officers and 16 victims of drug abuse. Data collection instruments used were: (1) interview guidelines, (2) questionnaires for material and media experts, (3) questionnaires for practitioners or officers and test subjects, (4) Cooper tests (12-minute run) for effectiveness tests. Data analysis techniques used are quantitative descriptive analysis and qualitative descriptive analysis, which are converted into a conversion table [10].

The effectiveness test was carried out by an experimental method, namely by comparing the results of the pretest with the results of the respondents' fitness posttest with a t-test of significance level of 5\%. Are a data collection technique that not only measures the attitudes of respondents (interviews and questionnaires) but can also be used to record various phenomena that occur (situations and conditions). can be corrected erroneously. The instrument used to measure the effectiveness of the product is a fitness test using the Cooper test. Implementation of the test as follows: Equipment; 400meter track, stopwatch, whistle, assistant. This test requires the testi to run as far as possible within 12 minutes. Test for 10 minutes to warm up. The assistant gives the command "GO", starts the stopwatch and the testi starts the test. The assistant continues to test the information of the time remaining at the end of each round $(400 \mathrm{~m})$. The assistant blows the whistle when 12 minutes have passed and records the testi distance.

The estimated VO2Max can be calculated as follows: The way to determine the VO2max value from the distance achieved when conducting a 12-minute cooper test is to use the formula, VO2 $\max =(22.35 \mathrm{x}$ kilometers $)-11.29$. After getting the VO2max score, to determine the level of physical fitness is aided by the cooper norm table, which can be seen below.

TABLE I. DATA The COOPER Norm TABLE For MeN

\begin{tabular}{|c|c|c|c|c|c|}
\hline Age & Excellent & $\begin{array}{c}\text { Above } \\
\text { Ave }\end{array}$ & Average & $\begin{array}{c}\text { Below } \\
\text { Ave }\end{array}$ & Poor \\
\hline $\begin{array}{l}\text { Male } \\
20-29\end{array}$ & $>2800 \mathrm{~m}$ & $\begin{array}{l}2400- \\
2800 \mathrm{~m}\end{array}$ & $\begin{array}{l}2200- \\
2399 m\end{array}$ & $\begin{array}{l}1600- \\
2199 \mathrm{~m}\end{array}$ & $\begin{array}{c}< \\
1600 \mathrm{~m}\end{array}$ \\
\hline $\begin{array}{l}\text { Males } \\
30-39\end{array}$ & $>2700 \mathrm{~m}$ & $\begin{array}{l}2300- \\
2700 \mathrm{~m}\end{array}$ & $\begin{array}{l}1900- \\
2299 \mathrm{~m}\end{array}$ & $\begin{array}{l}1500- \\
1999 \mathrm{~m}\end{array}$ & $\begin{array}{c}< \\
1500 \mathrm{~m}\end{array}$ \\
\hline $\begin{array}{l}\text { Males } \\
40-49\end{array}$ & $>2500 \mathrm{~m}$ & $\begin{array}{l}2100- \\
2500 \mathrm{~m}\end{array}$ & $\begin{array}{l}1700- \\
2099 m\end{array}$ & $\begin{array}{l}1400- \\
1699 \mathrm{~m}\end{array}$ & $\begin{array}{c}< \\
1400 \mathrm{~m}\end{array}$ \\
\hline $\begin{array}{c}\text { Males } \\
50+\end{array}$ & $>2400 \mathrm{~m}$ & $\begin{array}{l}2000- \\
2400 \mathrm{~m}\end{array}$ & $\begin{array}{l}1600- \\
1999 m\end{array}$ & $\begin{array}{l}1300- \\
1599 \mathrm{~m}\end{array}$ & $\begin{array}{c}< \\
1300 \mathrm{~m}\end{array}$ \\
\hline
\end{tabular}

TABLE II. DATA THE COOPER NORM TABLE FOR WOMEN

\begin{tabular}{|c|c|c|c|c|c|}
\hline Age & Excellent & $\begin{array}{c}\text { Above } \\
\text { Ave }\end{array}$ & Average & $\begin{array}{c}\text { Below } \\
\text { Ave }\end{array}$ & Poor \\
\hline $\begin{array}{c}\text { Females } \\
20-29\end{array}$ & $>2700 \mathrm{~m}$ & $2200-$ & $1800-$ & $1500-$ & $<$ \\
$2700 \mathrm{~m}$ & $2199 \mathrm{~m}$ & $1799 \mathrm{~m}$ & $1500 \mathrm{~m}$ \\
\hline Females & $>2500 \mathrm{~m}$ & $2000-$ & $1700-$ & $1400-$ & $<$ \\
$30-39$ & & $2500 \mathrm{~m}$ & $1999 \mathrm{~m}$ & $1699 \mathrm{~m}$ & $1400 \mathrm{~m}$ \\
\hline Females & \multirow{2}{*}{$2300 \mathrm{~m}$} & $1900-$ & $1500-$ & $1200-$ & $<$ \\
$40-49$ & & $2300 \mathrm{~m}$ & $1899 \mathrm{~m}$ & $1499 \mathrm{~m}$ & $1200 \mathrm{~m}$ \\
\hline Females & $>2200 \mathrm{~m}$ & $1700-$ & $1400-$ & $1100-$ & $<$ \\
$50+$ & & $2200 \mathrm{~m}$ & $1699 \mathrm{~m}$ & $1399 \mathrm{~m}$ & $1100 \mathrm{~m}$ \\
\hline
\end{tabular}

\section{RESULTS AND DISCUSSION}

After determining the product to be developed in the form of a fitness training manual for drug abuse victims at the NAPZA BRSPP Social Rehabilitation Service and 
Rehabilitation Center in Yogyakarta. The next step is to compile the product using the following steps: (1) gathering information or preliminary analysis of needs analysis by addiction and victims of drug abuse, (2) carry out planning includes defining the product to be developed, formulating objectives, estimating funding requirements, labor, and estimating time, (3) developing the initial product draft that includes the initial form of the product to be tested, including facilities / materials, sources / sources, research instruments, and validation of research by experts / experts before being trialled, (4) conducting preliminary field trials and examining the contents of instruments systematically and evaluating their relevance to specified variables, (5) revision of trial results after validating and getting input from experts / experts that the product has been valid and worthy of being tested, (6) carrying out research small-scale trial results, (7) product revisions, after analyzing deficiencies encountered in small-scale trials input received from experts / experts is followed up with product revisions, (8) carrying out large-scale trial research, (9) product revisions the final is refinement of large-scale research product that has been given input from experts / experts, (10) product effectiveness test.

DATA RESULTS OF PRACTICE AND TRIAL SUBJECT ASSESMENT OF PRODUCTS IN SMALL SCALE TESTS

\begin{tabular}{|c|c|c|c|c|c|c|c|c|c|c|c|c|}
\hline \multirow{3}{*}{$\begin{array}{l}\text { Number } \\
\text { session }\end{array}$} & \multicolumn{6}{|c|}{ Practitioners } & \multicolumn{6}{|c|}{ Subject of Assesment } \\
\hline & \multicolumn{3}{|c|}{ Media Display } & \multicolumn{3}{|c|}{ Content Material } & \multicolumn{3}{|c|}{ Media Display } & \multicolumn{3}{|c|}{ Content Material } \\
\hline & $\operatorname{Max}$ & $\begin{array}{l}\text { Real } \\
\text { Score }\end{array}$ & $\begin{array}{l}\text { Perce } \\
\text { ntage }\end{array}$ & $\operatorname{Max}$ & $\begin{array}{l}\text { Real } \\
\text { Score }\end{array}$ & $\begin{array}{l}\text { Perce } \\
\text { ntage }\end{array}$ & Max & $\begin{array}{l}\text { Real } \\
\text { Score }\end{array}$ & $\begin{array}{c}\text { Percen } \\
\text { tage }\end{array}$ & Max & $\begin{array}{l}\text { Real } \\
\text { Score }\end{array}$ & $\begin{array}{c}\text { Percen } \\
\text { tage }\end{array}$ \\
\hline $\begin{array}{c}\text { (Small } \\
\text { scale) }\end{array}$ & 176 & 158 & $\begin{array}{c}89.77 \\
\%\end{array}$ & 80 & 71 & $\begin{array}{c}88.89 \\
\%\end{array}$ & 264 & 232 & $\begin{array}{c}87.88 \\
\%\end{array}$ & 120 & 98 & $\begin{array}{c}81.67 \\
\%\end{array}$ \\
\hline $\begin{array}{l}\text { 2(Big } \\
\text { scale) }\end{array}$ & 176 & 167 & $\begin{array}{c}94.89 \\
\%\end{array}$ & 80 & 76 & $\begin{array}{c}95.00 \\
\%\end{array}$ & 704 & 689 & $\begin{array}{c}97.87 \\
\%\end{array}$ & 320 & 304 & $\begin{array}{c}95.00 \\
\%\end{array}$ \\
\hline
\end{tabular}

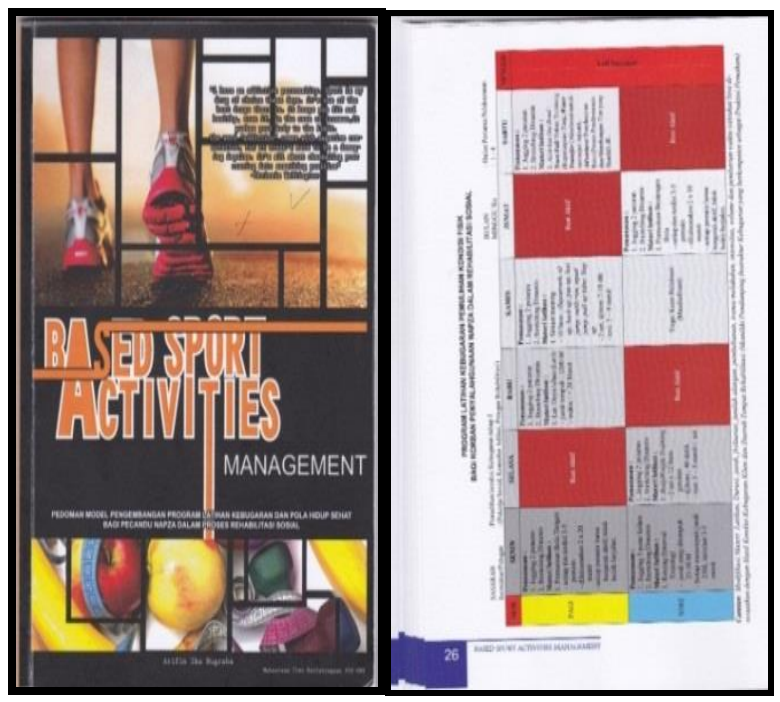

Fig. 1. Results of Revised Cover Stage 1

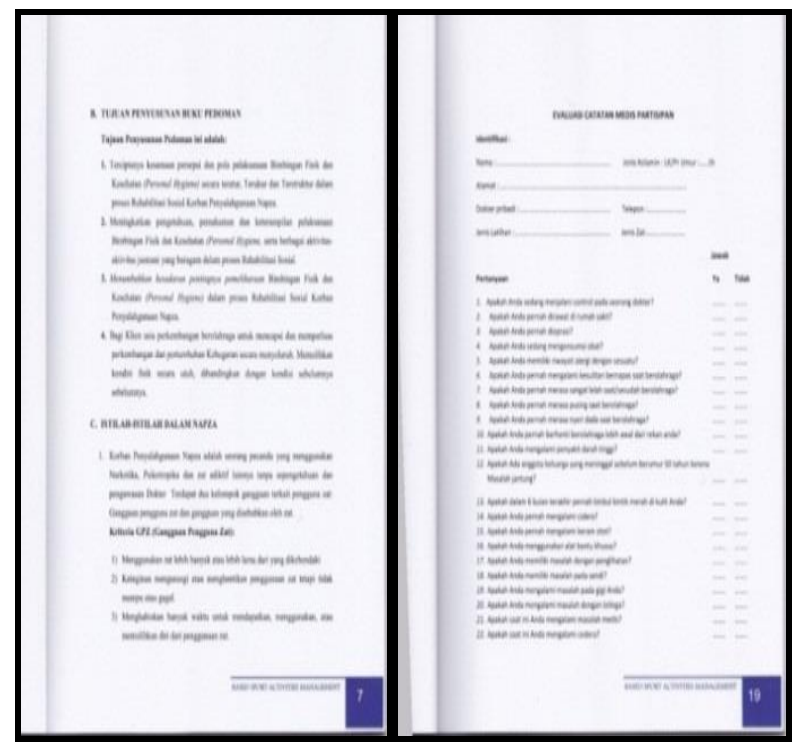

Fig. 2. Results of Revised Preliminary Phase 2 


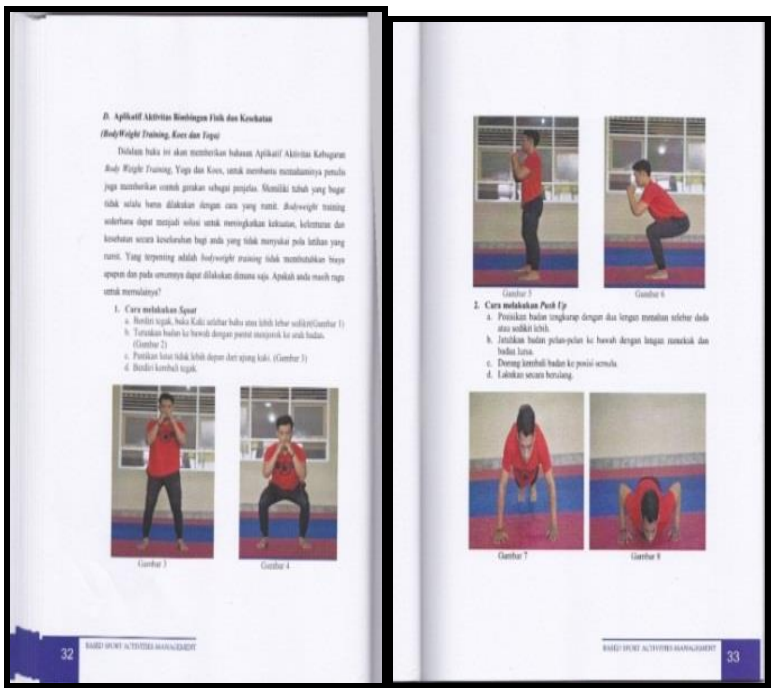

Fig. 3. Revision Results related to the applicative movement Phase 2

\section{CONCLUSION}

Products developed are fit to be used to improve fitness for victims of drug abuse in the Social Service and Rehabilitation Center of BRSPP Special Region of Yogyakarta. Fitness training program handbook for victims of drug abuse at the Social Service and Rehabilitation Center for BRRP Drug Special Region of Yogyakarta that has been compiled effectively in improving fitness. This is indicated by an increase in fitness during the effectiveness.

\section{ACKNOWLEDGMENT}

This work was supported by Universitas Musamus, Merauke Papua, Indonesia.

\section{REFERENCES}

[1] B. Indonesia, Standard TC rehabilitation for community self-help. Jakarta: tnp, 2012, 2012.

[2] Kementerian Sosial Republik Indonesia, Pedoman rehabilitasi sosial dengan metode therapeutic community (TC) bagi korban penyalahgunaan NAPZA (Guidelines for social rehabilitation using the therapeutic community (TC) method for victims of drug abuse),. Jakarta:, 2010.

[3] A. I. Nugroho and A. M. Fadlih, "Pengaruh Sumber Belajar Dasar Gerak Softball Terhadap Kemampuan Kognitif Mahasiswa PJKR UNMUS, (The Influence of basic learning resources for softball motion on the cognitive ability of PJKR UNMUS students)" Musamus J. Phys. Educ. Sport, vol. 2, no. 01, pp. 19-27, 2019.

[4] M. Chudley (Chad), “'A Sport-Based Intervention for Preventing Alcohol Use and Promoting Physical Activities Among Adolescents,"” ProQuest Nurs. Allied Heal. Source, pp. 73, 10, 2003.

[5] A. I. Nugroho, D. P. Saputro, A. K. Hidayat, M. Fadlih, and N. L. Djamudi, "Effectiveness of software for indonesian martial art," in IOP Conference Series: Earth and Environmental Science, 2019, vol. 343 , no. 1 , p. 12210.

[6] D. Sukadiyanto\&Muluk, Introduction to Theory and Physical Training Methodology. Bandung: CV LubukAgung, 2011.

[7] Kementerian Sosial Republik Indonesia \& Parahita, Refresher training NAPZA. Jakarta, 2015.

[8] Kementerian Sosial Republik Indonesia, Pedoman rehabilitasi sosial korban penyalahounaan NAPZA didalam lembaga (Guidelines for social rehabilitation for victims of drug abuse). Jakarta, 2012.

[9] A. \&Nandurkar B. Ahmed, ""Effect of Physical Exercise of Asana Yoga And Aerobics On Hematological Variables," Int. J. Heal. Phys. Educ. Comput. Sci. Sport, vol. 13, no. ISSN 2231-3265.Vol. No.13, p. pp 29-32, 2014.

[10] Sugiyono, Educational research methods (quantitative, qualitative 